\title{
Acoustic stimulation alters deoxyglucose uptake in the mouse cochlea and inferior colliculus
}

\author{
Barbara Canlon and Jochen Schacht \\ Kresge Hearing Research Institute, University of Michigan, Ann Arbor, MI 48I09. L.S.A.
}

(Received 1 September 1982: accepted 6 December 1982)

\begin{abstract}
Deoxyglucose uptake and activities of hexokinase and glucose-6-phosphatase in auditory structures (organ of Corti, stria vascularis and spiral ligament, modiolar section of VIIIth nerve. inferior colliculus) and non-auditory tissues (heart, kidney, liver) of the mouse were analyzed. [ $\left.{ }^{3} \mathrm{H}\right]$ Deoxyglucose was given as a pulse into the tail vein and uptake was quantitated by microdissection of tissues and scintillation counting. Radioactivity in cochlear tissues was maximal after 45-60 min and declined with a half-life of 30-60 min. Deoxyglucose 6-phosphate represented ca. 60\% of total radioactivity (heart, inferior colliculus. $>80 \%)$. The ratio of hexokinase to glucose-6-phosphatase activity was considerably lower in the auditory periphery than in brain. The rank order was inferior colliculus $\gg$ VIIIth nerve $\approx$ heart $>$ stria vascularis and spiral ligament $>$ kidney $>$ organ of Corti $\approx$ liver.

Exposure to broadband noise increased glucose utilization in all auditory structures. Uptake was maximally (2- to 3-fold) stimulated at moderate noise intensity (55-85 dBA). In addition, the auditory system showed two salient features: at high intensities (100 and $115 \mathrm{dBA}$ ) deoxyglucose uptake decreased from the maximum: and the non-sensory tissues of the cochlea (stria vascularis and spiral ligament) responded to sound parallel to the sensory structures at all levels of stimulus intensity. There were no effects of acoustic stimulation on serum glucose levels, serum kinetics of deoxyglucose. or deoxyglucose uptake into other body tissues.
\end{abstract}

Key words: deoxyglucose; auditory structures; energy metabolism; acoustic stimulation; noise.

\section{Introduction}

Biochemical correlates of acoustic transduction have yet to be established for the peripheral auditory system. Paradoxically, a wide variety of noise-induced changes in the tissues and fluids of the inner ear have been reported without providing a basis for an understanding of sound processing. Effects on DNA and RNA. protein synthesis, enzymatic activities, permeability and transport processes may reflect various stages in noise-induced trauma rather than molecular events related to auditory transduction. Quantitative biochemical studies, notably on high-energy metabolites, have failed to demonstrate effects of non-traumatic exposure to noise (for reviews, see $[6,21,24]$ ).

Since its introduction by Sokoloff et al. [23], the technique of 'deoxyglucose trapping' has been widely used to investigate the metabolic response of the central 
nervous system to physiological stimuli. In the present study we adapted the procedure for the auditory periphery to investigate deoxyglucose uptake in the cochlea and the inferior colliculus of the mouse in response to acoustic stimulation.

\section{Materials and Methods}

\section{Deoxyglucose uptake}

Conscious male mice (CBA, Charles River Laboratories), 412 weeks of age $(16-25 \mathrm{~g})$, were injected with a single pulse of $5 \mathrm{mCi} 2$-deoxy-D-1-[ $\left.{ }^{3} \mathrm{H}\right] \mathrm{glucose}$ (Amersham S.A., $40 \mathrm{mCi} / \mathrm{mmol}$ ) $/ \mathrm{kg}$ body wt in the tail vein (in approx. $0.2 \mathrm{ml}$ saline per injection). Immediately after the injection the animals were placed into a sound-shielded 'exposure box'. At various time intervals animals were killed, blood samples taken and the cochlea, inferior colliculus, kidney, liver and heart removed. The organs were quickly blotted on tissue paper to remove adhering blood and exposed to microwave irradiation $(1200 \mathrm{~W})$ for $15 \mathrm{~s}$ to arrest enzymatic activities. Prior to microwaving the cochlea, the inner ear fluids were absorbed with a cotton swab. Tissues were homogenized and aliquots taken for protein determination and scintillation counting. Aliquots were also processed for separation of deoxyglucose from deoxyglucose 6-phosphate by ion-exchange chromatography [9].

\section{Dissection of the inner ear}

The inner ear was hand dissected under a microscope into three components: (1) the 'organ of Corti' consisting of receptor cells, supporting cells and nerve fibers; (2) the lateral wall tissues, a combined preparation of the stria vascularis and spiral ligament; and (3) the modiolar portion of the VIIIth nerve.

\section{Sound exposure}

The exposure box $(40 \times 40 \times 40 \mathrm{~cm})$ had loud speakers mounted in the ceiling and was placed inside a soundproof room in order to obtain the lowest noise levels ( $25 \mathrm{dBA}, 42 \mathrm{dBB}, 56 \mathrm{dBC}$ ). Auditory stimulation was broadband noise ( $100 \mathrm{~Hz}$ to 45 $\mathrm{kHz}$ ) at intensities of up to $115 \mathrm{dBA}$. The spectrum was flat for frequencies up to 20 $\mathrm{kHz}$ and attenuated approx. $20 \mathrm{~dB}$ between 20 and $45 \mathrm{kHz}$. Noise levels were measured with a half-inch condensor microphone on the dBA scale.

\section{Biochemical assays}

Hexokinase (ATP:D-hexose-6-phosphotransferase, EC 2.7.1.1) and glucose-6phosphatase (glucose-6-phosphate phosphohydrolase, EC 3.1.3.9) were analyzed with the radioactive substrates, $\left[{ }^{3} \mathrm{H}\right]$ deoxyglucose and $\left[{ }^{3} \mathrm{H}\right]$ deoxyglucose 6-phosphate, respectively. Deoxyglucose was obtained from Sigma (St. Louis, Mo., U.S.A.) and $\left[{ }^{3} \mathrm{H}\right]$ deoxyglucose 6-phosphate was synthesized enzymatically [3]. Tissues were homogenized in $0.25 \mathrm{M}$ sucrose $/ 5 \mathrm{mM}$ potassium phosphate, $\mathrm{pH} 7.6$, and centrifuged for $10 \mathrm{~min}$ at $12000 \times \mathrm{g}$. The supernatant fraction was assayed for hexokinase in (final concentrations) $40 \mathrm{mM}$ potassium phosphate, $\mathrm{pH} 7.6,40 \mathrm{mM} \mathrm{KCl}, 5 \mathrm{mM}$ ATP, $5 \mathrm{mM} \mathrm{MgCl}_{2}, 0.1 \mathrm{mM}(10 \mathrm{nCi})$ deoxyglucose, total volume, $100 \mu 1$. The pellet 
was suspended in $50 \mathrm{mM}$ sodium cacodylate, $\mathrm{pH}$ 6.5, and assayed for glucose-6phosphatase with $0.1 \mathrm{mM}(10 \mathrm{nCi})$ deoxyglucose 6-phosphate, volume $100 \mu 1$ [7].

Protein [14] and glucose [2] were determined spectrophotometrically.

\section{Calculations}

All values of deoxyglucose uptake were calculated from the radioactivity in the tissue per $\mu \mathrm{g}$ tissue protein and corrected for serum levels of $\left[{ }^{3} \mathrm{H}\right]$ deoxyglucose. Serum glucose levels were not taken into account as they did not change with noise exposure. Furthermore, a 'lumped constant' necessary for the calculation of absolute metabolic rates [23] cannot be obtained for individual cochlear tissues. Even if it were technically feasible to measure arterio-venous differences between the labyrinthine artery and the vein of the cochlear aqueduct, these would only reflect the combined metabolism of the whole cochlea and the vestibular system.

\section{Results}

\section{Deoxyglucose uptake}

Deoxyglucose uptake in the organ of Corti, lateral wall tissues, and VIIIth nerve was maximal between 45 and 60 min ( Fig. 1), when the ratio of deoxyglucose to deoxyglucose 6-phosphate had also reached an equilibrium [4]. A rapid decline of radioactivity thereafter indicated a short half-life of the radioactive compounds in

\section{TABLE I}

\section{PHOSPHORYLATION OF [ ${ }^{3}$ H]DEOXYGLUCOSE AND ENZYMATIC ACTIVITIES IN MOUSF TISSUES}

Phosphorylation (in vivo): Animals received a pulse of $5 \mathrm{mCi}\left[{ }^{3} \mathrm{H}\right]$ deoxyglucose $/ \mathrm{kg}$ body wt and were killed at $60 \mathrm{~min}$. Tissues were analyzed as described in Methods and deoxyglucose 6-phosphate was separated by ion-exchange chromatography [9]. There was no difference of phosphorylation with varying noise intensities. Numbers are means \pm S.D. with number of animals in parentheses. Enzymatic activities (in vitro) were determined from initial rates (1-3 or 2-5 min) as described in Methods. Ratios are taken from means of duplicate experiments.

\begin{tabular}{lll} 
Tissue & $\begin{array}{l}\text { Deoxyglucose 6-phosphate } \\
\text { (\% of total radioactivity) }\end{array}$ & $\begin{array}{l}\text { Enzyme activities } \\
\text { (Hexokinase/ } \\
\text { glucose-6-phosphatase) }\end{array}$ \\
\hline Organ of Corti & $56 \pm 10(28)$ & 1.6 \\
I.ateral wall tissues & $63 \pm 9(28)$ & 3.5 \\
Inner ear fluids & $10 \pm 7(5)$ & -3 \\
VIIIth nerve & $76 \pm 8(15)$ & 6.5 \\
Inferior colliculus & $84 \pm 4(12)$ & 14.3 \\
Heart & $82 \pm 5(18)$ & 5.5 \\
Kidney & $47 \pm 9(13)$ & 2.2 \\
Liver & $29 \pm 14(7)$ & 1.5 \\
\hline
\end{tabular}

\footnotetext{
a Not determined.
} 
the inner ear tissues. in the organ of Corti deoxyglucose 6-phosphate comprised 55\% of total radioactivity, in the lateral wall tissues $63 \%$ and in VIIIth nerve and inferior colliculuc about $80 \%$ (Table I). For comparison, heart showed a conversion to the phosphate of $82 \%$, while kidney and liver were lowest (approx. $40 \%$ ). Inner ear fluids contained almost no phosphorylated product.

\section{Enzymatic activities}

The activities of hexokinase and glucose-6-phosphatase of cochlear tissues were compared to those of the inferior colliculus, kidney, heart and liver. Assays were carried out with $25-50 \mu \mathrm{g}$ of protein for 3-5 min since under these conditions enzymatic rates were linear with respect to both time and protein. Activities for inferior colliculus were typical for structures of the central nervous system, high hexokinase and low phosphatase activity [7]. In contrast, cochlear tissues had lower hexokinase levels and higher phosphatase activities (Table I).

\section{Effects of acoustic stimulation}

Noise exposure increased the levels of deoxyglucose in all auditory tissues (Fig. 1). Since the $60 \mathrm{~min}$ time point showed optimal incorporation, phosphorylation, and a clearly established effect of noise, it was chosen for subsequent experiments (Fig. 2). Deoxyglucose uptake in both the cochlear tissues and the inferior colliculus increased two- to three-fold with auditory stimulation of moderate intensity (55-85 dBA). At higher intensities (100 and $115 \mathrm{dBA}$ ) the rate of glucose utilization decreased but still remained somewhat higher than at rest. Radioactivity in inner ear fluids apparently did not follow this pattern. After corrections for inter-animal differences in serum radioactivity the fluids contained $165 \pm 45 \mathrm{dpm}$ at

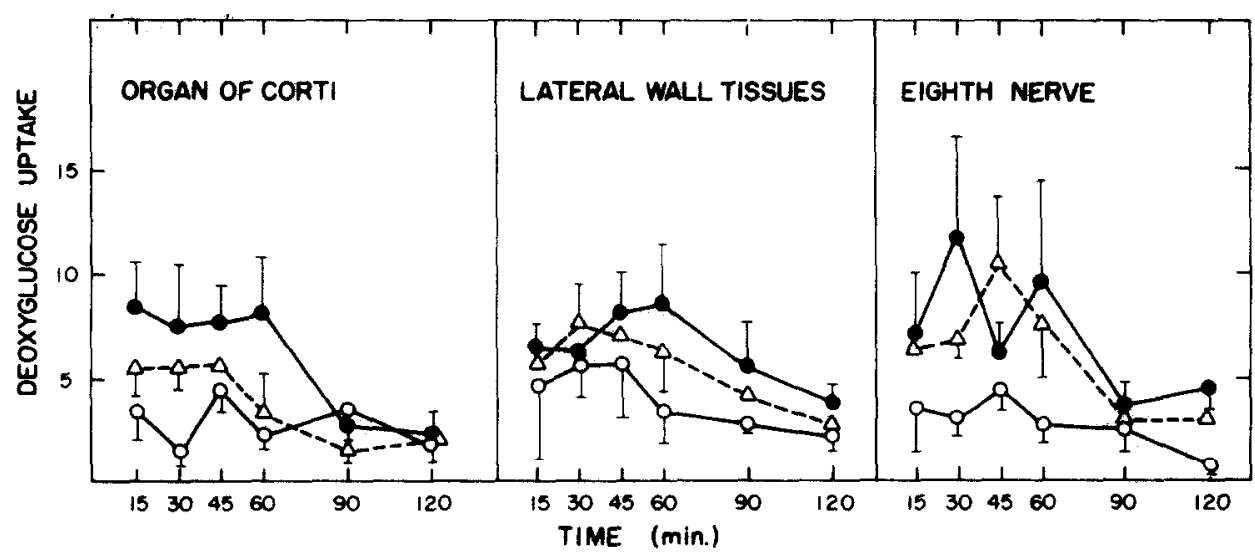

Fig. 1. Time course of deoxyglucose uptake into cochlear tissues. Animals received a pulse of $5 \mathrm{mCi}$ $\left[{ }^{3} \mathrm{H}\right]$ deoxyglucose $/ \mathrm{kg}$ body weight and were killed at times indicated. Deoxyglucose uptake was determined as described in Methods. Values are means \pm S.D. for 3 to 6 animals each. $O$, no sound exposure; $\bullet$, exposure to $45 \mathrm{dBA} ; \triangle$, exposure to $100 \mathrm{dBA}$ white noise during the time of the experiment. $\mathrm{CB} 57 / \mathrm{J}$ mice (6-12 weeks old) were used. 


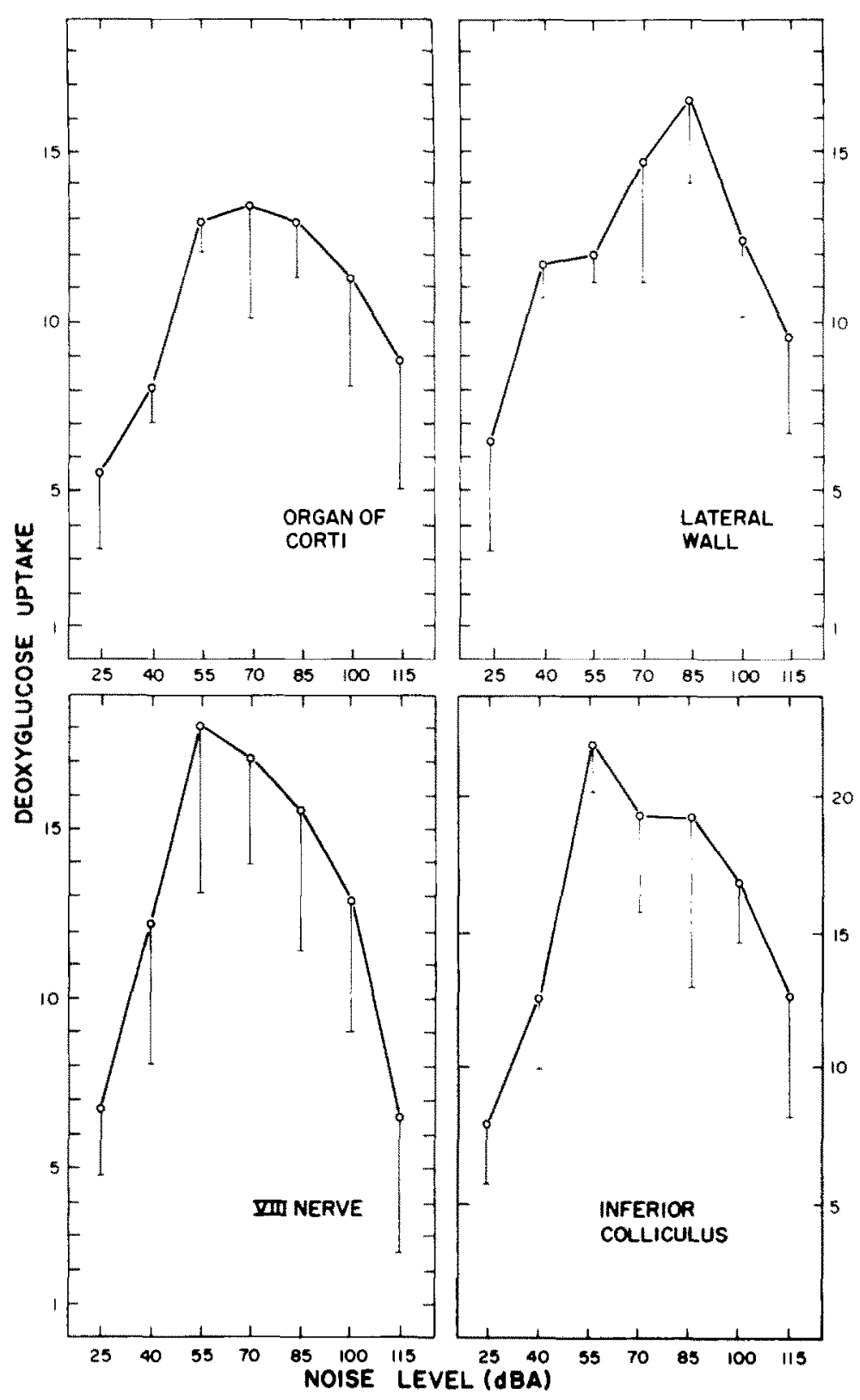

Fig. 2. Response of deoxyglucose uptake to noise exposure. Animals received a pulse of $5 \mathrm{mCi}$ $\left[{ }^{3} \mathrm{H}\right]$ deoxyglucose $/ \mathrm{kg}$ body wt and were killed after $60 \mathrm{~min}$ of exposure to the noise levels indicated. Deoxyglucose uptake was determined as described in Methods. Values are means \pm S.D. from 3 to 8 animals each. Differences between $25 \mathrm{dBA}$ and $85 \mathrm{dBA}$ and between $85 \mathrm{dBA}$ and $115 \mathrm{dBA}$ are significant at $P<0.001$ for all tissues. 
$25 \mathrm{dBA}(n=7), 222 \pm 110 \mathrm{dpm}$ at $85 \mathrm{dBA}(n=5)$ and $244 \pm 127 \mathrm{dpm}$ at $115 \mathrm{dBA}$ $(n=4)$.

Several parameters were tested to determine possible systemic responses to noise exposure. Kinetics of $\left[{ }^{3} \mathrm{H}\right]$ deoxyglucose in the serum remained unaltered by noise exposure as did serum glucose levels. This was established both for early times (to $60 \mathrm{~s}$ ) where the peak of serum radioactivity occurred and for later times corresponding to the conditions of sound exposure (Fig. 3).

Moreover, glucose utilization in the renal cortex, liver and heart appeared to be

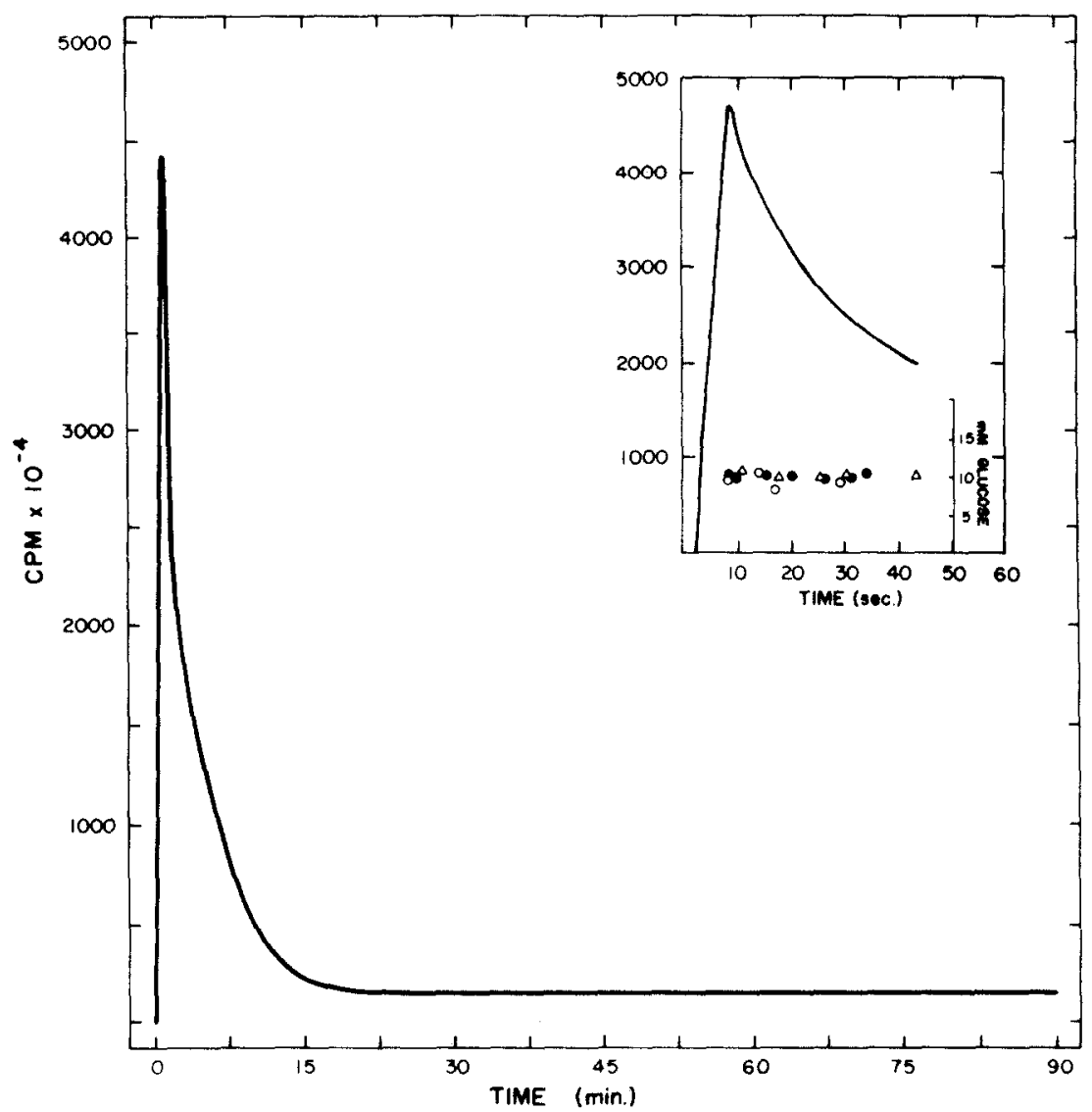

Fig. 3. Time course of serum radioactivity and glucose levels. Animals received a pulse of $5 \mathrm{mCi}$ $\left[{ }^{3} \mathrm{H}\right.$ ]deoxyglucose $/ \mathrm{kg}$ body weight and were exposed to noise as described in Methods. For radioactivity, 58 serum samples were analyzed for the time of $2-60 \mathrm{~s}$ after exposure $(n=16$ at $25 \mathrm{dBA}, n=24$ at 85 $\mathrm{dBA}, n=18$ at $115 \mathrm{dBA}$ ); at later times (15, 30, 45, 60 and $90 \mathrm{~min}) 3-6$ samples were analyzed at each dB level. Serum kinetics did not differ with noise exposure ( $P>0.5$; two-way ANOVA). Data from all sound exposures was combined to construct the curves by polynomial best-fit. Glucose values are from individual samples at $25 \mathrm{dBA}(O), 85 \mathrm{dBA}(O)$ and $115 \mathrm{dBA}(\Delta)$. Serum glucose levels at 60 min were (means \pm S.D. from five animals per group): $10.0 \pm 2.4 \mathrm{mM}(25 \mathrm{dBA}) .11 .5 \pm 1.1 \mathrm{mM}$ (85 dBA), and $11.3 \pm 0.8 \mathrm{mM}$ (115 dBA). 
TABLE II

EFFECT OF ACOUSTIC STIMULATION ON DEOXYGLUCOSE UPTAKE IN NON-AUDITORY TISSUES

Animals received a pulse of $5 \mathrm{mCi}\left[{ }^{3} \mathrm{H}\right]$ deoxyglucose $/ \mathrm{kg}$ body weight and were killed after $60 \mathrm{~min}$. Deoxyglucose uptake was determined as described in Methods. Numbers are means \pm S.D. with number of animals in parentheses.

\begin{tabular}{lcrr}
\hline Tissue & \multicolumn{2}{l}{ Deoxyglucose uptake } & $115 \mathrm{dBA}$ \\
\cline { 2 - 4 } & $25 \mathrm{dBA}$ & $85 \mathrm{dBA}$ & $1.9 \pm 0.4(7)$ \\
\hline Liver & $2.2 \pm 0.5(9)$ & $3.4 \pm 1.9(11)^{*}$ & $4.5 \pm 2.8(7)$ \\
Kidney & $4.5 \pm 2.3(8)$ & $7.1 \pm 3.3(11)^{* *}$ & $19.1 \pm 10.3(3)$ \\
Heart & $16.5 \pm 5.2(3)$ & $14.1 \pm 4.9(3)$ & \\
\hline
\end{tabular}

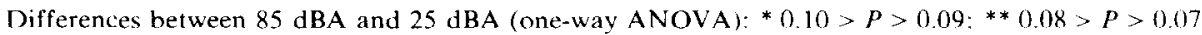

independent of the auditory stimulus (Table II). However, since the somewhat elevated deoxyglucose levels in kidney and liver had $P$ values between 0.05 and 0.1 . the data were more closely inspected. Further analysis showed that of the 11 animals exposed to $85 \mathrm{dBA}, 7$ gave a cluster of values indistinguishable from controls at 25 dBA $(4.9 \pm 1.4$ for kidney; $2.2 \pm 0.6$ S.D. for liver $)$. Two animals each had higher uptake into either kidney or liver, and only two animals showed increased uptake into both kidney (13.1 and 9.7) and liver (6.1 and 4.5). In addition, results from two small groups of animals $(n=4)$ exposed to 70 or $100 \mathrm{dBA}$ did not differ significantly from control values. In contrast, all values in all stimulated ( $85 \mathrm{dBA})$ cochlear tissues were higher than all corresponding control values and the significance of these differences was $P<0.001$.

\section{Discussion}

Glucose utilization in the inner ear exhibited two salient features: (1) a biphasic response to the sound stimulus, and (2) a response to sound of the non-sensory tissues of the lateral wall of the cochlea. Before the significance of these findings can be assessed, however, it seems indicated to discuss the application of the deoxyglucose technique to the inner ear.

Deoxyglucose 'trapping' in the cochlea differs from that in brain in that the ratio of deoxyglucose 6-phosphate to deoxyglucose is considerably lower and the half-life of radioactivity is shorter. Such results are suggestive of a high glucose-6-phosphatase activity in the organ of Corti and the tissues of the lateral wall as confirmed by direct enzymatic analysis. The rank order of activities in brain (high hexokinase, low phosphatase), kidney and liver (low hexokinase, high phosphatase) is in good agreement with previously reported enzymatic activities on 2-deoxy-2-fluoro-D-glucose [7]. The enzymatic pattern of the cochlear tissues is apparently closer to body tissues such as kidney or liver than to the central nervous system. High glucose-6- 
phosphatase activity may cause dephosphorylation and loss of deoxyglucose postmortem from tissues where surgical access is difficult and time consuming as in the cochlea. Our technique of arresting enzymatic activities by microwave irradiation and microdissection of the tissues should minimize artifacts.

It is interesting that deoxyglucose uptake was maximally stimulated at physiological levels of sound (55-85 dBA). The effects of noise can only be observed when control animals are completely shielded from ambient noise confirming for the cochlea what had been demonstrated for central auditory pathways [22]. Comparison with previous reports of deoxyglucose trapping in the inner ear is difficult because of the use in those studies of tissues embedded for light or electron microscopy $[18,19,20]$. Such preparations may retain only a fraction of the trapped deoxyglucose and of this a significant amount may be associated with glycogen granules [12,18]. In their radioautographic study in the gerbil, Ryan et al. [19] observed sound-stimulated deoxyglucose uptake in the VIIIth nerve but not in stria vascularis and only marginally in the organ of Corti. Not only the differences in the analytical methods but also in the sound stimulus and species preclude a direct comparison with our data.

Noise, particularly at high intensities, can cause stress to an animal [16]. It appears, however, that general systemic responses do not influence deoxyglucose trapping in the inner ear. Serum glucose levels and kinetics of $\left[{ }^{3} \mathrm{H}\right]$ deoxyglucose remain unchanged over the intensities given. Furthermore, deoxyglucose uptake into non-auditory tissues is not dependent on acoustic stimulation. Therefore, the observed changes seem specific for the auditory structures.

A striking feature of glucose utilization in the auditory periphery is the decrease at high stimulus intensities, the reasons for which remain speculative. Sound-induced increase in hair cell permeability has been reported [7] but we do not find the increased radioactivity in the inner ear fluids that would be expected if such a change were occurring. Moreover, since VIIIth nerve and inferior colliculus follow the pattern of the cochlear tissues, a genuine stimulus-related phenomenon is suggested. A somewhat similar phenomenon of decreased glucose utilization at high stimulus intensities has been reported for the retina [15] and damage to retinal rods was suggested as the cause. The decrease we observe in the cochlea could similarly result from injury to hair cells and represent a noise-induced threshold shift. Hair cell damage due to noise trauma is well documented [11] but highly variable with exposure conditions and animal species. Preliminary results from our laboratory indicate that exposure to $115 \mathrm{dBA}$ for $60 \mathrm{~min}$ does not induce permanent metabolic damage to the cochlea.

It should be considered that a biphasic response to sound stimulation can also be observed in electrophysiological responses of the ear. For instance, the cochlear microphonic potential rises with stimulus intensity of pure tones and decreases with overstimulation [24]. While differences in experimental parameters (pure tones of short duration in anesthetized animals in electrical recordings; continuous broadband noise and conscious animals in our study) do not permit direct comparisons it is nevertheless possible that the same mechanisms underly the electrophysiological and metabolic observations. These might include the stapedius reflex, efferent 
inhibition or adaptation [5,17]. More likcly, a reduction in local blood flow and consequent ischemia could be responsible for the decrease. Vasoconstriction of cochlear vessels in response to sound of high intensities has been reported [10] but remains controversial [1]. Morphological and histological investigations under the conditions of our experiments are needed to test these hypotheses.

The other salient finding of our study is the response of the non-sensory tissues of the cochlea to acoustic stimulation. The stria vascularis and the spiral ligament do not receive innervation, yet their deoxyglucose uptake is stimulated parallel with that of organ of Corti, VIIIth nerve and inferior colliculus. The functional role of the stria vascularis is presumed to be the maintenance of the endolymphatic potential. a resting potential crucial for the function of the auditory end-organ. Electrical activity of the receptor cells in the organ of Corti could alter potassium or sodium fluxes in the endolymph and thus provide an electrical feedback from the hair cells to the stria vascularis. Another explanation for the coupling of metabolism between the lateral wall tissues and the organ of Corti is the possible effect on blood flow of the sound stimulus. Control of blood flow in the cochlea may be located at the modiolar level where a vasomotor innervation is present [13]. Thus, if both the increase and decrease of glucose utilization are paralleled by increases and decreases of cochlear blood flow, then the organ of Corti and the lateral wall tissues should be equally affected.

In summary, the increase of glucose utilization of the auditory periphery with moderate acoustic stimulation provides a good analogy to central auditory structures and their response to physiological stimuli. The specific features of glucose utilization in the cochlea, the decrease with high noise intensities and the response of the non-neural tissues require further investigation. The first phenomenon may represent an early stage of noise-induced trauma while the second may provide new insights into cochlear physiology.

\section{Acknowledgements}

This research was supported by research grant NS-12881, program project grant NS-05785 and training grant NS-07106 from the National Institutes of Health. We are thankful to the Michigan Diabetes Research and Training Center, Biochemistry Core Laboratory, for performing blood glucose analyses (supported by grant P60AM20572 from NIADDKD).

\section{References}

1 Axelson. A. and Vertes, D. (1982): Histological findings in cochlear vessels after noise. In: New Perspectives on Noise-Induced Hearing Loss, pp. 95-102. Editors: R.P. Hamernik. D. Henderson and R. Salvi. Raven Press, New York.

2 Bergmeyer. H.U., Bernt. E., Schmidt. F. and Stork. H. (1974): Metabolites: Carbohydrate metabolism. In: Methods of Enzymatic Analysis, pp. 1205-1212. Editor: H.U. Bergmeyer. Verlag Chemie. Weinheim. 
3 Bessell, E.M. and Thomas, P. (1974): The deoxyfluoro-D-glucopyranose-6-phosphates and their effect on yeast glucose phosphate isomerase. Biochem. J. 131, 77-82.

4 Canlon, B. and Schacht, J. (1981): The effect of noise on deoxyglucose uptake into inner ear tissues of the mouse. Arch. Otorhinolaryngol. 230, 171-176.

5 Dallos, P. (1973): The auditory periphery, pp. 465-510. Academic Press, New York.

6 Drescher, D.G. (1976): A review of general cochlear biochemistry in normal and noise-exposed ears. In: Effects of Noise on Hearing, pp. 111-125. Editors: D. Henderson, R.P. Hamernik, D.S. Dosanjh and J.H. Mills. Raven Press, New York.

7 Gallagher, B.M., Fowler, J.S., Gutterson, N.I., MacGregor, R.R., Wan, C-N. and Wolf, A.P. (1978): Metabolic trapping as a principle of radiopharmaceutical design: some factors responsible for the biodistribution of ${ }^{18}$ F-2-deoxy-2-fluoro-D-glucose. J. Nucl. Med. 190, 1154-1161.

8 Goldstein, A.J. (1973): Permeability of the organ of Corti. Ann. Otol. 82, 166-174.

9 Hassell, J.A., Colby, C. and Romano, A. (1975): The effect of serum on the transport and phosphorylation of 2-deoxyglucose by untransformed and transformed mouse $3 \mathrm{~T} 3$ cells. J. Cell Physiol. 86, 37-45.

10 Hawkins, J.E. (1971): The role of vasoconstriction in noise-induced hearing loss. Ann. Otol. 80. $903-913$.

11 Hunter-Duvar, I.M., Suzuki, M. and Mount, R.J. (1982): Anatomical changes in the organ of Corti after acoustic stimulation. In: New Perspectives in Noise-Induced Hearing Loss, pp. 3-21. Editors: R.P. Hamernik, D. Henderson and R. Salvi. Raven Press. New York.

12 Kai Kai, M.A. and Pentreath, V.W. (1981): High resolution analysis of ${ }^{3} \mathrm{H}$ 2-deoxyglucose incorporation into neurons and glial cells in invertebrate ganglia: histological processing of nervous tissue for selective marking of glycogen. J. Neurocytol. 10, 693-708.

13 Kimura, R.S. and Ota, C.Y. (1974): Ultrastructure of the cochlear blood vessels. Acta Otolaryngol. 77. 231-250.

14 Lowry, O.H., Rosebrough, N.J., Farr, A.L. and Randall, R.J. (1951): Protein measurement with the Folin phenol reagent. J. Biol. Chem. 193, 265-275.

15 Miyaoka, M., Shinohara, M., Batipps, M., Pettigrew, K.D., Kennedy, C. and Sokoloff, L. (1979): The relationship between the intensity of the stimulus and the metabolic response in the visual system of the rat. Acta Neurol. Scand. Suppl. 72, 60, 16-17.

16 Peterson, E.A., Augenstein, J.S., Tanis, D.C. and Augenstein, D.G. (1981): Noise raises blood pressure without impairing auditory sensitivity. Science $211,1450-1452$.

17 Prijs, V.F. and Eggermont, J.J. (1981): Narrow-band analysis of compound action potentials for several stimulus conditions in the guinea pig. Hearing Res. 4, 23-41.

18 Pujol, R., Sans, A. and Calas, A. (1981): High-resolution radioautographic study of the inner ear following in vivo tritiated deoxyglucose administration. Eur. Neurol. 20, 156-161.

19 Ryan, A.F., Goodwin, P., Woolf, N.K. and Sharp, F. (1982): Auditory stimulation alters the pattern of 2-deoxyglucose uptake in the inner ear. Brain Res. 234, 213-225.

20 Sans, A., Pujol, R., Carlier, E. and Calas, A. (1980): Détection cellulaire de l'incorporation in vivo de 2-déoxyglucose tritié. Etude radioautographique dans l'oreille interne. C.R. Acad. Sc. Paris, Ser. D, $290,1225-1227$.

21 Schacht, J. (1982): Biochemical aspects of noise-induced hearing loss. In: New Perspectives on Noise-Induced Hearing Loss, pp. 95-102. Editors: R.P. Hamernik, D. Henderson and R. Salvi. Raven Press, New York.

22 Sokoloff, L. (1977): Relation between physiological function and energy metabolism in the central nervous system. J. Neurochem. 29, 13-26.

23 Sokoloff, L., Reivich, R.M., Kennedy, C., Des Rosiers, M.H., Patlack, C.S., Pettigrew, K.D., Sakurada, O. and Shinohara, M. (1977): The ${ }^{14} \mathrm{C}$-deoxyglucose method for measurement of local cerebral glucose utilization. J. Neurochem. 28, 897-916.

24 Thalmann, R. (1975): Biochemical studies of the auditory system. In: The Nervous System, Vol. 3, pp. 31-44. Editor: D.B. Tower. Raven Press, New York.

25 Wever, E.G. and Lawrence, M. (1954): Physiological Acoustics, pp. 117-144. Princeton University Press, Princeton. 